
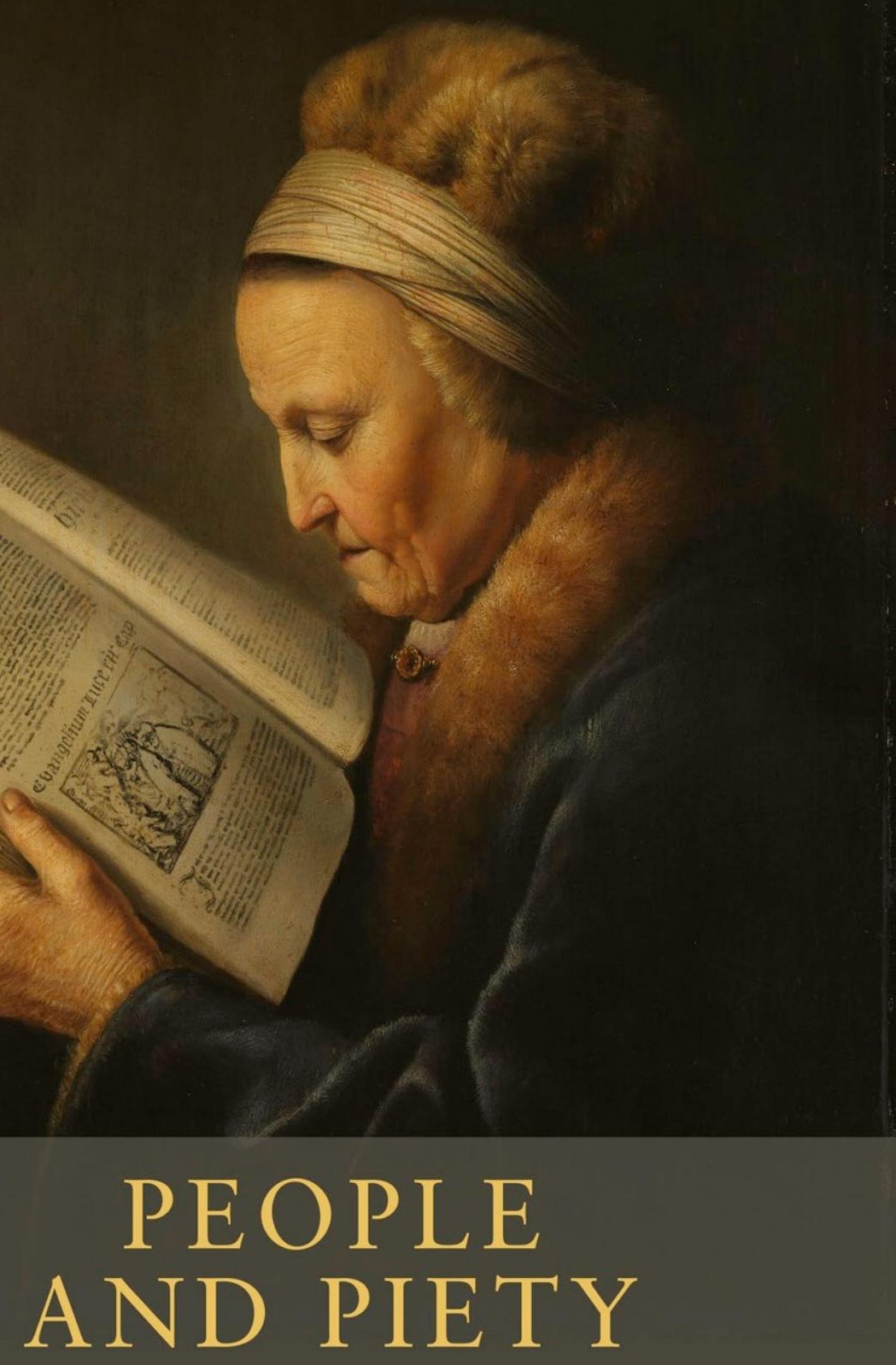

PROTESTANT DEVOTIONAL IDENTITIES IN EARLY MODERN ENGLAND

Edited by Elizabeth Clarke and Robert W. Daniel 


\section{People and piety}

\section{MANCHESTER 1824}

Manchester University Press 


\section{SEAA \\ des XVII* et XVIII* siècles \\ XVII-XVIII}

SEVENTEENTH- AND EIGHTEENTH-CENTURY STUDIES

General editors

Ladan Niayesh and Marie-Jeanne Rossignol

Founding editor

Anne Dunan-Page

Seventeenth- and Eighteenth-Century Studies promotes interdisciplinary work on the period c.1603-1815, covering all aspects of the literature, culture and history of the British Isles, colonial and post-colonial America and other British colonies. The series welcomes academic monographs, as well as collective volumes of essays, that combine theoretical and methodological approaches from more than one discipline to further our understanding of the period and geographical areas. It is supported by the Société d'Études Anglo-Américaines des XVIIe et XVIIIe siècles.

\section{Previously published}

Bellies, bowels and entrails in the eighteenth century

Edited by Rebecca Anne Barr, Sylvie Kleiman-Lafon and

Sophie Vasset

Writing and constructing the self in Great Britain in the long eighteenth century

Edited by John Baker, Marion Leclair and Allan Ingram

Radical voices, radical ways: Articulating and disseminating radicalism in seventeenth-and eighteenth-century Britain

Edited by Laurent Curelly and Nigel Smith

Frontiers of servitude: Slavery in narratives of the early French Atlantic

Michael Harrigan

The challenge of the sublime: From Burke's Philosophical Enquiry to British Romantic art

Hélène Ibata

English Benedictine nuns in exile in the seventeenth century:

Living spirituality

Laurence Lux-Sterritt 


\title{
People and piety
}

\section{Protestant devotional identities in early modern England}

\author{
Edited by \\ Elizabeth Clarke and Robert W. Daniel
}

Manchester University Press 
While copyright in the volume as a whole is vested in Manchester University Press, copyright in individual chapters belongs to their respective authors, and no chapter may be reproduced wholly or in part without the express permission in writing of both author and publisher.

Published by Manchester University Press

Altrincham Street, Manchester M1 7JA

www.manchesteruniversitypress.co.uk

British Library Cataloguing-in-Publication Data

A catalogue record for this book is available from the British Library

ISBN 9781526150127 hardback

First published 2020

The publisher has no responsibility for the persistence or accuracy of URLs for any external or third-party internet websites referred to in this book, and does not guarantee that any content on such websites is, or will remain, accurate or appropriate.

Cover image: Gerard Dou, Old Woman

Reading, c. 1631-2. Rijksmuseum. A.H.

Hoekwater Bequest, The Hague.

Cover design: riverdesignbooks.com

Typeset

by New Best-set Typesetters Ltd 